\title{
EKSTRAKSI UBI JALAR UNGU (Ipomoea batatas L.) MENGGUNAKAN VARIASI PELARUT SERTA PEMANFAATANNYA SEBAGAI INDIKATOR ASAM-BASA
}

\author{
Extraction of Purple Sweet Potato (Ipomoea batatas L.) Using Solvent Variation \\ and Its Utilization as Acid-Base Indicator
}

*Moh. Azhar Afandy, Siti Nuryanti dan Anang Wahid M. Diah

Pendidikan Kimia/FKIP - Universitas Tadulako, Palu - Indonesia 94118

Recieved 03 March 2017, Revised 04 April 2017, Accepted 04 May 2017

\begin{abstract}
Purple sweet potato (Ipomoea batatas L.) is one source of carbohydrate. Purple sweet potato contains vitamins and minerals that needed by humans such as vitamin $A$, vitamin $C$, calcium and iron. The sweet potato with purple flesh are widely used as natural dyes. Dyes called anthocyanins. The study aim was to determine a suitable solvent to extract the purple sweet potato. Variation of solvent used namely methanol, methanol acidified with $\mathrm{HCl} 1 \%$ and solvent fractionation (n-hexane, ethyl acetate, and methanol). The extraction phase was divided into two, for flesh and for skin of purple sweet potato. The extraction results were then compared with phenolphthalein indicator and a methyl orange on acid-base titration. The results showed that the methanol acidified with $\mathrm{HCl} 1 \%$ provided a more stable color changes in acid-base testing, and the testing of phosphate buffer pH 1-12. Purple sweet potato extracts can be used as an acid-base indicator because it gave similar results with comparative indicators, phenolphthalein and methyl orange.
\end{abstract}

Keywords: purple sweet potato, anthocyanin, acid-base indicators.

\section{Pendahuluan}

Ubi jalar (Ipomoea batatas L.) atau yang biasa dikenal dengan ketela rambat atau "sweet potato" diduga berasal dari benua Amerika. Para ahli Botani dan pertanian memperkirakan daerah asal tanaman ubi jalar adalah daerah Selandia Baru, Polinesia, dan Amerika bagian tengah. Penyebaran ubi jalar pertama kali terjadi ke Spanyol melalui Tahiti, Kepulauan Guam, Fiji, dan Selandia Baru. Orang-orang Spanyol dianggap berjasa menyebarkan ubi jalar ke kawasan Asia, terutama Filipina, Jepang dan Indonesia (Rukmana, 1997).

Warna merah dan ungu pada bunga, batang, daun, dan umbi merupakan akibat dari adanya senyawa antosianin. Keberadaan senyawa antosianin pada ubi jalar ungu atau merah dapat berfungsi sebagai komponen pangan sehat dan paling lengkap (Hambali, dkk., 2014). Antosianin pada ubi jalar ungu tidak kalah banyak jika dibandingkan

*Correspondence:

Moh. Azhar Afandy

Program Studi Pendidikan Kimia, Fakultas Keguruan dan

Ilmu Pendidikan, Universitas Tadulako

email: azharafandy32@gmail.com

Published by Universitas Tadulako 2017 dengan tumbuhan jenis lain yaitu berkisar antara 14,68 - $210 \mathrm{mg} / 100 \mathrm{~g}$ bahan baku (Kristijarti \& Arlene, 2012). Sekitar 80\% dari total antosianin tersebut berada dalam bentuk terasilasi. Antosianin yang terasilasi relatif lebih stabil jika dibandingkan dengan antosianin yang tidak terasilasi. Oleh karena itu, antosianin pada ubi jalar ungu berpotensi besar sebagai sumber pewarna alami. Jenis pelarut antosianin secara nyata mempengaruhi warna yang diekspresikannya. Sifat antosianin yang hidrofilik menyebebkan antosianin sering diekstraksi dengan menggunakan pelarut alkohol atau air. Pelarut alkohol akan menghasilkan warna yang lebih biru dibandingkan dengan pelarut air (Andarwulan \& Faradilla, 2012). Kestabilan warna senyawa antosianin dipengaruhi oleh $\mathrm{pH}$ atau tingkat keasaman, dan akan lebih stabil apabila dalam suasana asam atau $\mathrm{pH}$ yang rendah (Arja, dkk., 2013).

Titrasi asam basa pada prinsipnya merupakan reaksi netralisasi. Sehingga biasa disebut titrasi netralisasi. Larutan analit pada titrasi netralisasi bisa berupa asam lemah, asam kuat, basa lemah, basa kuat, ataupun garam 
yang bersifat asam maupun basa (Pursitasari, 2014). Menentukan titik ekuivalen dalam suatu titrasi harus mengetahui dengan tepat berapa volume basa yang ditambahkan dari buret ke asam dalam labu erlenmeyer. Salah satu cara untuk mencapai tujuan tersebut ialah dengan menambahkan beberapa tetes indikator asam-basa ke larutan asam saat awal titrasi. Indikator biasanya adalah suatu asam atau basa organik lemah dengan warna yang sangat berbeda antara bentuk tidak terionisasi dan terionisasinya (Chang, 2003)

Indikator alami titrasi asam basa dari ubi jalar ungu diharapkan mampu menanggulangi berbagai masalah yang dihadapi oleh guru dalam penggunaan indikator asam basa. Hal tersebut dikarenakan bahan baku yakni ubi jalar ungu mudah diperoleh jika dibandingkan dengan indikator sintesis yang umumnya mempunyai harga yang mahal. Selain mempunyai harga yang mahal, indikator sintetis sangat sulit dijumpai di sekolah-sekolah yang berada di daerah terpencil karena keterbatasan alat dan bahan untuk menunjang proses pembelajaran.

Tulisan ini dimaksudkan untuk mengetahui jenis pelarut yang cocok digunakan dalam proses ekstraksi ubi jalar ungu sebagai indikator asam basa. Selain itu, studi ini diharapkan mampu membantu mengalihkan penggunaan indikator sintesis dengan indikator yang berasal dari bahan alam yang lebih ekonomis dan ramah lingkungan.

\section{Metode \\ Alat dan Bahan}

Alat-alat yang digunakan dalam penelitian ini adalah gelas kimia, gelas ukur, spatula, shacker, pipet tetes, buret, klem dan statif, plat tetes, neraca digital, corong, erlenmeyer, dan $\mathrm{pH}$ meter.

Bahan-bahan yang digunakan dalam penelitian ini adalah umbi dan kulit ubi jalar ungu, aquades, metanol (Merck), etil asetat (Merck), n-heksana (Merck), $\mathrm{HCl}$ (Merck), $\mathrm{NaOH}\left(\right.$ Merck), $\mathrm{CH}_{3} \mathrm{COOH}(M e r c k), \mathrm{NH}_{4} \mathrm{OH}$ (Merck), indikator fenolftalein, indikator metil oranye, kertas saring, aluminium foil dan kertas HVS.

\section{Prosedur penelitian}

Ekstraksi Umbi dan Kulit Ubi Jalar Ungu

Sebanyak masing-masing 50 gram umbi dan kulit ubi jalar ungu ditimbang dan dimasukkan ke dalam erlenmeyer kemudian ditambahkan dengan $100 \mathrm{~mL}$ n-heksana. Campuran tersebut kemudian dimaserasi selama 6 jam. Ekstrak kemudian disaring dan residunya dimaserasi kembali dengan $100 \mathrm{~mL}$ etil asetat selama 6 jam. Residu hasil ekstraksi selanjutnya dimaserasi kembali dengan $100 \mathrm{~mL}$ metanol selama 12 jam. Setelah itu ekstrak tersebut disaring dan siap untuk digunakan sebagai indikator asambasa (Nuryanti, dkk., 2010).

\section{Ekstraksi dengan Pelarut Metanol}

Sebanyak masing-masing 50 gram umbi dan kulit ubi jalar ungu dan dimasukkan ke dalam erlenmeyer kemudian ditambahkan dengan $100 \mathrm{~mL}$ metanol dan dimaserasi selama 12 jam. Setelah itu ekstrak tersebut disaring dan siap untuk digunakan sebagai indikator asam-basa (Siregar, 2009)

\section{Ekstraksi dengan Pelarut Metanol yang Diasamkan dengan $\mathrm{HCl}$ 1\%}

Sebanyak masing-masing 50 gram umbi dan kulit ubi jalar ungu ditimbang dan dimasukkan ke dalam erlenmeyer kemudian ditambahkan dengan $100 \mathrm{~mL}$ metanol yang diasamkan dengan $1 \mathrm{~mL} \mathrm{HCl} 1 \%$ dan dimaserasi selama 12 jam. Setelah itu ekstrak tersebut di saring dan siap untuk digunakan sebagai indikator asam-basa.

\section{Identifikasi Senyawa Antosianin}

Ekstrak umbi dan kulit ubi jalar ungu yang diperoleh diteteskan pada kertas HVS dan diuapkan dengan uap amonia selama beberapa saat sampai terjadi perubahan warna (Harborne, 1996).

Pengujian Warna pada Larutan Asam dan Basa

Ekstrak umbi dan kulit ubi jalar yang diperoleh diteteskan ke dalam larutan asam $(\mathrm{HCl} \mathrm{0,1} \mathrm{M)} \mathrm{dan} \mathrm{larutan} \mathrm{basa}(\mathrm{NaOH} 0,1 \mathrm{M})$ kemudian bandingkan warna yang dihasilkan dari ketiga ekstrak dari jenis pelarut yang berbeda tersebut (Rahmawati, 2015).

\section{Pengujian pada Buffer pH 1-12}

Ekstrak umbi dan kulit ubi jalar yang diperoleh diteteskan ke dalam buffer fosfat $\mathrm{pH}$ 1-12. Bandingkan warna yang diperoleh dari beberapa ekstrak tersebut berdasarkan perubahan warna yang diamati (Rahmawati, 2015).

\author{
Pengujian melalui Titrasi Asam-Basa. \\ Titrasi Asam Kuat - Basa Kuat \\ $20 \mathrm{~mL} \mathrm{HCl} \mathrm{0,1} \mathrm{M} \mathrm{dimasukkan} \mathrm{ke} \mathrm{dalam}$
}


erlenmeyer dan ditambahkan dengan 3 tetes ekstrak umbi ubi jalar ungu, kemudian dititrasi dengan $\mathrm{NaOH}$ 0,1 M. Selanjutnya diukur perubahan $\mathrm{pH}$ selama titrasi berlangsung, dan dilakukan 3 kali pengulangan. Hal yang sama dilakukan dengan menggunakan 3 tetes ekstrak kulit ubi jalar ungu dan 3 tetes indikator fenolftalein sebagai pengganti 3 tetes ekstrak umbi ubi jalar ungu (Nuryanti, dkk., 2010).

\section{Titrasi Asam Lemah - Basa Kuat}

$20 \mathrm{~mL} \mathrm{CH}_{3} \mathrm{COOH}$ 0,1 M dimasukkan ke dalam erlenmeyer dan ditambahkan dengan 3 tetes ekstrak umbi ubi jalar ungu, kemudian dititrasi dengan $\mathrm{NaOH} 0,1 \mathrm{M}$. Selanjutnya diukur perubahan $\mathrm{pH}$ selama titrasi berlangsung, dan dilakukan 3 kali pengulangan. Hal yang sama dilakukan dengan menggunakan 3 tetes ekstrak kulit ubi jalar ungu dan 3 tetes indikator fenolftalein sebagai pengganti 3 tetes ekstrak umbi ubi jalar ungu (Nuryanti, dkk., 2010).

\section{Titrasi Basa Lemah - Asam Kuat}

$20 \mathrm{~mL} \mathrm{NH}_{4} \mathrm{OH}$ 0,1 M dimasukkan ke dalam erlenmeyer dan ditambahkan dengan 3 tetes ekstrak umbi ubi jalar ungu, kemudian dititrasi dengan $\mathrm{HCl}$ 0,1 M. Selanjutnya diukur perubahan $\mathrm{pH}$ selama titrasi berlangsung, dan dilakukan 3 kali pengulangan. Hal yang sama dilakukan dengan menggunakan 3 tetes ekstrak kulit ubi jalar ungu dan 3 tetes indikator metil oranye sebagai pengganti 3 tetes ekstrak umbi ubi jalar ungu (Nuryanti, dkk., 2010).

\section{Hasil dan Pembahasan}

\section{Ekstraksi Umbi dan Kulit Ubi Jalar Ungu}

50 gram umbi dan kulit ubi jalar ungu dimaserasi selama 6 jam dengan pelarut n-heksana. Ekstraksi dengan metode maserasi didasarkan pada sifat kelarutan dari komponen didalam pelarut yang digunakan (Siregar \& Nurlela, 2011). Penggunaan pelarut $n$-heksana bertujuan untuk menarik senyawa non polar yang terdapat pada umbi dan kulit ubi jalar ungu. Residu yang diperoleh kemudian dimaserasi kembali selama 6 jam dengan pelarut etil asetat. Hal tersebut dimaksudkan untuk menarik komponen-kompenen semipolar yang kemungkinan tidak berperan sebagai indikator (Frantauansyah, 2013). Residu hasil ekstraksi kemudian dimaserasi kembali dengan pelarut metanol selama 12 jam. Hasil yang diperoleh kemudian disaring untuk mendapatkan ekstrak umbi dan kulit ubi jalar ungu yang siap digunakan sebagai indikator.

Hal yang sama dilakukan terhadap sampel melalui maserasi dengan pelarut metanol selama 12 jam. Penggunaan metanol sebagai pelarut dikarenakan sifatnya yang polar. Antosianin merupakan komponen yang bersifat polar sehingga pelarut yang digunakan juga harus bersifat polar (Bridle \& Timberlake, 1997). Hasil yang diperoleh kemudian disaring dan siap digunakan sebagai indikator.

Ekstraksi juga dilakukan terhadap sampel dengan maserasi menggunakan pelarut metanol yang diasamkan dengan $\mathrm{HCl} 1 \%$. Tujuan dari penambahan $\mathrm{HCl} 1 \%$ yaitu untuk membuat proses ekstraksi berlangsung dalam suasana asam dan diharapkan akan semakin banyak jumlah antosianin yang dapat diperoleh. Ekstraksi antosianin dapat dilakukan dengan berbagai jenis pelarut tetapi yang paling efektif adalah dengan menggunakan metanol yang diasamkan dengan HCl (Hambali, dkk., 2014). Penambahan $\mathrm{HCl}$ juga berfungsi untuk menstabilkan antosianin agar tidak mudah teroksidasi (Lestari, dkk., 2014). Hasil yang diperoleh menunjukkan bahwa ekstrak umbi dan kulit ubi jalar ungu yang dimaserasi dengan pelarut metanol yang diasamkan dengan $\mathrm{HCl}$ $1 \%$ memiliki warna yang lebih pekat jika dibandingkan dengan ekstrak umbi dan kulit ubi jalar ungu yang menggunakan pelarut metanol dan fraksionasi pelarut.

\section{Identifikasi Senyawa Antosianin}

Hasil pengamatan yang diperoleh menunjukkan bahwa ekstrak umbi dan kulit dari ubi jalar ungu tersebut positif mengandung senyawa antosianin yang ditandai dengan adanya perubahan warna dari merah menjadi biru setelah diuapkan dengan menggunakan uap amonia. Kandungan antosianin ubi jalar ungu adalah turunan peonidin dan sianidin (Gambar 1) (Suda, dkk., 2003). Sianidin merupakan turunan antosianin yang paling umum yang memberikan warna merah lembayung (Harborne, 1996).

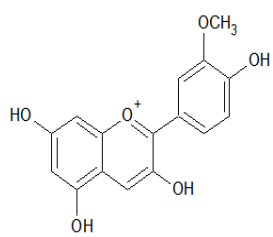

(a)

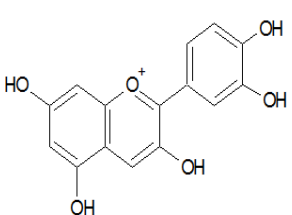

(b)
Gambar 1. Struktur peonidin (a) dan sianidin (b) (Suda, dkk., 2003) 
Pengujian Warna Pada Larutan Asam dan Basa Hasil pengujian ekstrak kulit dan umbi ubi jalar ungu pada larutan asam dan basa berturutturut dengan fraksionasi pelarut, pelarut metanol yang diasamkan dengan $\mathrm{HCl} 1 \%$ dan pelarut metanol dapat dilihat pada Gambar 2, 3, dan 4. Hasil pengamatan menunjukkan semua ekstrak mengalami perubahan warna merah pada asam dan berwarna hijau pada basa.

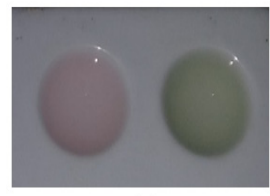

(a)

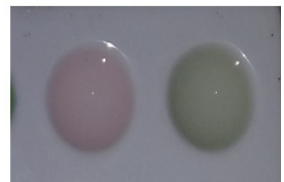

(b)
Gambar 2. Warna indikator (a) umbi dan (b) kulit ubi jalar ungu dengan fraksionasi pelarut.

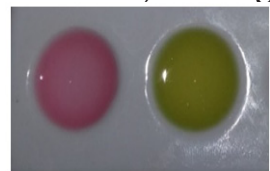

(a)

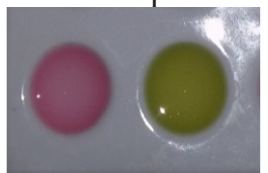

(b)
Gambar 3. Warna indikator (a) umbi dan (b) kulit ubi jalar ungu dengan pelarut metanol.

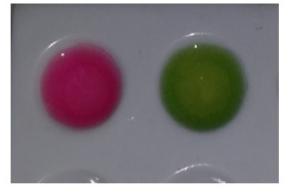

(a)

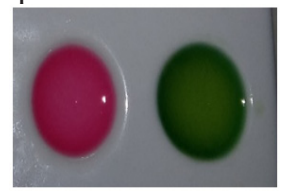

(b)
Gambar 4. Warna indikator (a) umbi dan (b) kulit ubi jalar ungu dengan pelarut metanol yang diasamkan dengan $\mathrm{HCl} 1 \%$.

Kemampuan indikator umbi dan kulit ubi jalar ungu untuk berubah warna pada asam dan basa disebabkan oleh adanya antosianin. Ketiga gambar di atas menunjukkan perubahan warna indikator umbi dan kulit ubi jalar ungu pada berbagai jenis pelarut. Jika dibandingkan, perubahan warna yang dihasilkan mempunyai perbedaan yang cukup mencolok. Indikator umbi dan kulit ubi jalar ungu yang menggunakan pelarut metanol yang diasamkan dengan $\mathrm{HCl}$ menghasilkan warna yang lebih pekat. Hal ini disebabkan karena pada kondisi $\mathrm{pH}$ yang sangat asam warna dari senyawa antosianin berada dalam kondisi stabil dan paling berwarna (Andarwulan \& Faradilla, 2012).

\section{Pengujian Pada Buffer pH 1-12}

Larutan penyangga (buffer) merupakan larutan dari asam lemah dan basa konjugatnya atau basa lemah dengan konjugatnya. Sifat utama dari larutan penyangga adalah daya tahannya terhadap perubahan $\mathrm{pH}$ akibat penambahan sejumlah kecil asam kuat atau basa kuat (Goldberg, 2003). Pengujian dilakukan dengan cara meneteskan ekstrak umbi dan kulit ubi jalar ungu pada buffer $\mathrm{pH}$ 1-12. Ekstrak umbi dan kulit ubi jalar yang menggunakan variasi pelarut tersebut akan dibandingkan perubahan warna sebagai acuan untuk penggunaan indikator pada tahapan titrasi asam-basa. (lihat Tabel 1)

Tabel 1. Hasil pengujian pada buffer untuk ekstrak umbi dan kulit ubi jalar ungu

\begin{tabular}{|c|c|c|c|}
\hline Jenis Pelarut & $\begin{array}{l}\text { Larutan } \\
\text { Buffer }\end{array}$ & $\begin{array}{c}\text { Warna Indikator } \\
\text { Umbi Ubi Jalar } \\
\text { Ungu }\end{array}$ & $\begin{array}{c}\text { Warna Indikator } \\
\text { Kulit Ubi Jalar } \\
\text { Ungu }\end{array}$ \\
\hline $\begin{array}{c}\text { Fraksionasi } \\
\text { pelarut }\end{array}$ & $\mathrm{pH} 1-12$ & Tidak berwarna & Tidak berwarna \\
\hline Metanol & $\begin{array}{c}\mathrm{pH} 1-9 \\
\mathrm{pH} 10-12\end{array}$ & $\begin{array}{l}\text { Merah muda } \\
\text { Hijau }\end{array}$ & $\begin{array}{l}\text { Merah muda } \\
\text { Hijau }\end{array}$ \\
\hline $\begin{array}{c}\text { Metanol }+\mathrm{HCl} \\
1 \%\end{array}$ & $\begin{array}{c}\mathrm{pH} \mathrm{1-9} \\
\mathrm{pH} 10-12\end{array}$ & $\begin{array}{l}\text { Merah muda } \\
\text { Hijau }\end{array}$ & $\begin{array}{l}\text { Merah muda } \\
\text { Hijal }\end{array}$ \\
\hline
\end{tabular}

Hasil pengujian pada buffer $\mathrm{pH}$ 1-12 dari beberapa ekstrak tersebut menunjukkan bahwa indikator ekstrak umbi dan kulit yang dimaserasi dengan menggunakan fraksionasi pelarut pada rentang buffer $\mathrm{pH}$ 1-12, Warna merah muda dan hijau yang ditimbulkan tidak terlalu mencolok dan cenderung tidak berwarna. Hasil pengujian pada buffer $\mathrm{pH}$ 1-12 untuk ekstrak umbi dan kulit ubi jalar ungu yang dimaserasi dengan menggunakan pelarut metanol menunjukkan adanya 2 kelompok warna yaitu berwarna merah muda pada rentang $\mathrm{pH}$ 1-9 dan berwarna hijau pada rentang $\mathrm{pH}$ 10-12. Hal yang sama juga diperoleh pada ekstrak umbi dan kulit ubi jalar ungu yang dimaserasi dengan pelarut metanol yang diasamkan dengan $\mathrm{HCl}$ 1\%. Hasil yang diperoleh menunjukkan adanya 2 kelompok warna yaitu merah muda pada rentang $\mathrm{pH} 1-9$ dan berwarna hijau pada rentang $\mathrm{pH}$ 10-12. Warna merah muda yang dihasilkan pada $\mathrm{pH}$ asam akan semakin memudar seiring dengan meningkatnya $\mathrm{pH}$. Hal tersebut dikarenakan sifat dari senyawa antosianin itu sendiri yang stabil pada $\mathrm{pH}$ asam. Antosianin lebih stabil dalam media asam pada $\mathrm{pH}$ rendah daripada dalam larutan alkali dengan $\mathrm{pH}$ tinggi (Rein, 2005). Hasil yang diperoleh tersebut dapat menjadi indikasi untuk menentukan rentang $\mathrm{pH}$ dari indikator umbi dan kulit 
ubi jalar ungu berdasrkan perubahan warna yang terjadi. Trayek $\mathrm{pH}$ dari suatu indikator dapat ditentukan dengan alat yang mampu membedakan panjang gelombang dari warna warni indikator (Day \& Underwood, 2002). Bentuk kesetimbangan dan perubahan struktur dari senyawa antosianin pada berbagai kondisi $\mathrm{pH}$ dapat dilihat pada Gambar 5.<smiles>[R]c1cc(C=C)cc(C2=C(O)CC3C(=O)C=C(O)C=C3OC2c2cc([R])c(O)c([R])c2)c1</smiles><smiles>[R2]c1cc(C(O)=Cc2c(O)cc(O)cc2O)c(O)cc1C(O)=CC</smiles>

Gambar 5. Kesetimbangan antosianin dalam larutan (Rein, 2005).

Gambar 5 menjelaskan bahwa di dalam larutan terdapat empat bentuk kesetimbangan antosianin yaitu kation flavilium, basa quinoidal, karbinol (pseudobasa) dan kalkon (Bakowska-Barczak, 2005). Di bawah pH rendah, antosianin berada dalam bentuk kation flavilium merah. Saat pH dinaikkan (>5), akan mempercepat kehilangan proton sehingga membentuk basa quinoidal yang cenderung menjadi biru atau ungu, selain itu kenaikkan $\mathrm{pH}$ menyebabkan hidrasi kation flavilium untuk membentuk karbinol (pseudobasa) atau kalkon yan tidak berwarna (Rein, 2005). Warna ekstrak antosianin ubi jalar ungu secara konsisten hanya dipengaruhi oleh $\mathrm{pH}$ yaitu berubah dari merah, merah pudar, ungu, biru, hijau dan kuning seiring dengan kenaikkan $\mathrm{pH}$ 1 hingga $\mathrm{pH} 14$ (Mahmudatussa'adah, dkk., 2014).

\section{Pengujian Pada Titrasi Asam-Basa}

Berdasarkan beberapa pengujian awal yang telah dilakukan, indikator umbi dan kulit ubi ungu yang menggunakan pelarut metanol yang diasamkan dengan $\mathrm{HCl} 1 \%$ dipilih sebagai indikator untuk tahapan titrasi asam basa karena memiliki perubahan warna yang cenderung lebih pekat dan terang sehingga akan memudahkan saat menentukan titik akhir titrasi.

Hasil pengamatan terhadap titrasi asam kuatbasa kuat untuk penggunaan indikator umbi ubi jalar ungu titik akhir titrasi yang diperoleh yaitu pada penambahan $19 \mathrm{~mL} \mathrm{NaOH} \mathrm{0,1} \mathrm{M}$ dengan $\mathrm{pH}$ rata-rata yaitu 7,78 (lihat Gambar 6). Perubahan warna yang terjadi dari merah muda menjadi hijau dan untuk penggunaan indikator kulit ubi jalar ungu, titik akhir titrasi yang diperoleh yaitu pada penambahan 19,2 $\mathrm{mL} \mathrm{NaOH} 0,1 \mathrm{M}$ dengan $\mathrm{pH}$ rata-rata yaitu 9,06. Perubahan warna yang terjadi dari merah muda menjadi hijau. Indikator pembanding yakni indikator fenolftalein, titik akhir titrasi yang diperoleh yaitu pada penambahan 18,8 $\mathrm{mL} \mathrm{NaOH} 0,1 \mathrm{M}$ dengan $\mathrm{pH}$ rata-rata yaitu 8,55 serta perubahan warna yang terjadi dari tak berwarna menjadi merah muda.

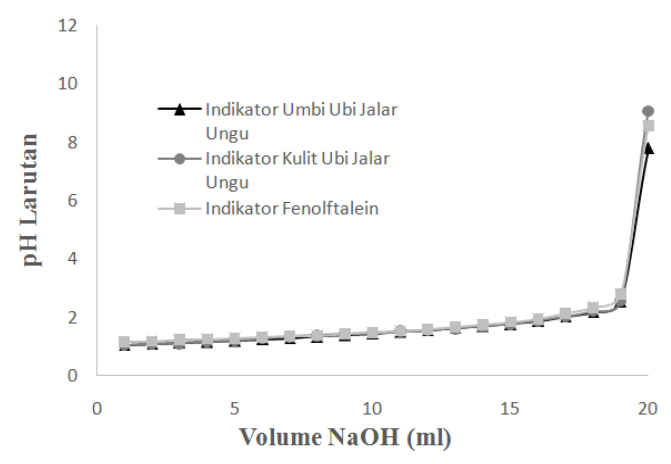

Gambar 6. Kurva titrasi asam kuat-basa kuat

Hasil pengamatan terhadap titrasi asam lemah-basa kuat untuk penggunaan indikator umbi ubi jalar ungu diperoleh titik akhir titrasi pada penambahan $19,4 \mathrm{~mL} \mathrm{NaOH} 0,1 \mathrm{M}$ dengan $\mathrm{pH}$ rata-rata 7,32 (lihat Gambar 7). Perubahan warna yang terjadi dari merah muda menjadi hijau. Pada penggunaan indikator kulit ubi jalar ungu, diperoleh titik akhir titrasi pada penambahan 19,2 mL $\mathrm{NaOH} 0,1 \mathrm{M}$ dengan $\mathrm{pH}$ rata-rata 7,73 . Perubahan warna yang terjadi dari merah muda menjadi hijau. Sedangkan untuk indikator pembanding yakni indikator fenolftalein, titik akhir titrasi yang diperoleh yaitu pada penambahan $19,5 \mathrm{~mL}$ $\mathrm{NaOH} 0,1 \mathrm{M}$ dengan $\mathrm{pH}$ rata-rata 8,52 serta perubahan warna yang terjadi dari tak berwarna menjadi merah muda.

Kurva titrasi asam lemah-basa kuat tersebut yang menggunakan indikator umbi dan kulit ubi jalar ungu dengan indikator pembanding yaitu indikator fenolftalein menunjukkan bahwa nilai $\mathrm{pH}$ dari ketiga indikator tersebut tidak terlalu jauh berbeda. Berdasarkan rentang 


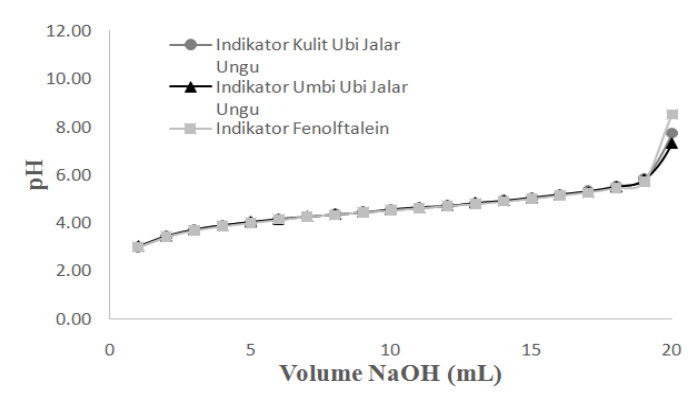

Gambar 7. Kurva titrasi asam lemah-basa kuat $\mathrm{pH}$ dari penambahan $0 \mathrm{~mL}$ sampai $20 \mathrm{~mL}$ $\mathrm{NaOH} 0,1 \mathrm{M}$ cenderung berimpitan sehingga hasilnya tidak jauh berbeda. Hal tersebut menandakan bahwa indikator umbi dan kulit ubi jalar ungu dapat digunakan dalam titrasi asam lemah-basa kuat.

Hasil pengamatan pada titrasi basa lemahasam kuat untuk penggunaan indikator umbi ubi jalar ungu diperoleh titik akhir titrasi pada penambahan 19,4 mL HCl 0,1 M dengan $\mathrm{pH}$ rata-rata 5,50 (lihat Gambar 8). Perubahan warna dari hijau menjadi merah muda. Penggunaan indikator kulit ubi jalar ungu, diperoleh titik akhir titrasi pada penambahan $19,8 \mathrm{~mL} \mathrm{HCl} 0,1 \mathrm{M}$ dengan $\mathrm{pH}$ rata-rata 5,39. Perubahan warna dari hijau menjadi merah muda. Pada indikator pembanding yang digunakan yaitu indikator metil oranye, diperoleh titik akhir titrasi pada penambahan 19,7 $\mathrm{mL} \mathrm{HCl}$ dengan $\mathrm{pH}$ rata-rata 5,32 serta perubahan warna dari kuning menjadi merah.

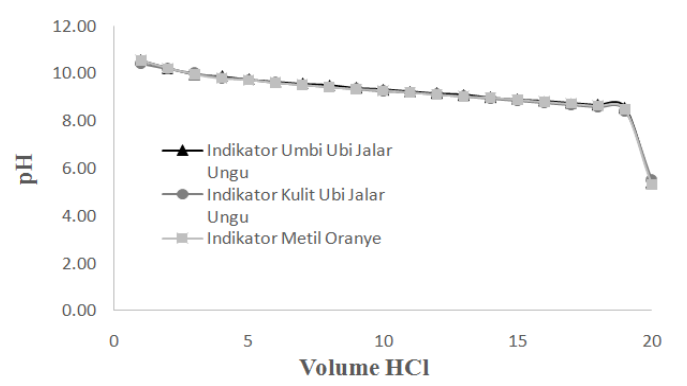

Gambar 8. Kurva titrasi basa lemah-asam kuat

Berdasarkan kurva titrasi basa lemah-asam kuat yang menggunakan indikator umbi dan kulit ubi jalar ungu dengan indikator metil oranye sebagai pembanding, menunjukkan bahwa nilai $\mathrm{pH}$ yang diperoleh dari ketiga indikator tersebut tidak jauh berbeda. Kurva yang dihasilkan cenderung berimpitan dan tidak memiliki perbedaan yang signifikan. Hal tersebut dapat mengindikasikan bahwa penggunaan indikator umbi dan kulit ubi jalar ungu dapat digunakan untuk titrasi basa lemah-asam kuat.

Senyawa-senyawa organik yang dapat digunakan sebagai indikator dalam titrasi mempunyai karakteristik yaitu senyawa memberikan perubahan warna terhadap perubahan suasana $\mathrm{pH}$ larutan. Perubahan warna dapat terjadi melalui proses keseimbangan bentuk molekul dan ion dari senyawa indikator tersebut (Nuryanti, dkk., 2010).

\section{Kesimpulan}

Jenis pelarut yang paling cocok digunakan dalam proses ekstraksi umbi dan kulit ubi jalar ungu yaitu pelarut metanol yang diasamkan dengan $\mathrm{HCl} 1 \%$ yang menunjukkan warna yang lebih stabil dibandingkan dengan jenis pelarut lainnya.

\section{Ucapan Terima Kasih}

Ucapan terimakasih penulis sampaikan kepada Tim Penelitian Kimia Organik Pendidikan Kimia FKIP Universitas Tadulako yang telah memberikan bantuan dana penelitian melalui dana hibah Fakultas Keguruan dan Ilmu Pendidikan Universitas Tadulako

\section{Referensi}

Andarwulan, N. \& Faradilla, R. F. (2012). Pewarna alami untuk pangan. Bogor: Seafast Center.

Arja, F. S., Darwis, D. \& Santoni, A. (2013). Isolasi, identifikasi, dan uji antioksidan senyawa antosianin dari buah sikaduduk (melastoma malabathricum l) serta aplikasi sebagai pewarna alami. Jurnal Kimia Unand, 2(1), 124-127.

Bakowska-Barczak, A. (2005). Acylated anthocyanins as stable, natural food colorants - A review. Polish Journal of Food and Nutrition Sciences, 14(2), 107-116.

Bridle, P. \& Timberlake, C. F. (1997). Anthocyanins as natural food colours selected aspects. Food Chemistry, 1(2), 103109.

Chang, R. (2003). General chemistry: The essential concepts. Jakarta: Erlangga.

Day, R. A. \& Underwood, A. L. (2002). Analisis kimia kuantitatif. Jakarta: Erlangga.

Frantauansyah. (2013). Ekstrak bunga waru (bibiscus tiliaceus) sebagai indikator asam- 
basa. Skripsi sarjana pada program studi Pendidikan Kimia Universitas Tadulako Palu, Tidak Diterbitkan.

Goldberg, E. D. (2003). Schaum's easy outlines kimia untuk pemula. Jakarta: Erlangga.

Hambali, M., Mayasari, F. \& Noermansyah, F. (2014). Ekstraksi antosianin dari ubi jalar dengan variasi konsentrasi solven dan lama waktu ekstraksi. Teknik Kimia, 20(2), 2535 .

Harborne, J. B. (1996). Metode fitokimia penuntun cara modern menganalisis tumbuhan. Bandung: ITB.

Kristijarti, A. P. \& Arlene, A. (2012). Isolasi zat warna ungu pada ipomoea batatas poir dengan pelarut air. Universitas Katolik Parahyangan: Lembaga penelitian dan pengabdian kepada masyarakat.

Lestari, P. P., Kusrini, D. \& Anam, K. (2014). Anthocyanin identification of methanol$\mathrm{HCl}$ extract active fraction in rosella (hibiscus sabdariffa l) and its potential as xanthine oxidase inhibitor. Jurnal Sains dan Matematika, 22(3), 72-78.

Mahmudatussa'adah, A., Fardiaz, D., Andarwulan, N. \& Kusnandar, F. (2014). Karakteristik warna dan aktivitas antioksidan antosianin ubi jalar ungu. Jurnal Teknologi dan Industri Pangan, 25(2), 176-184.

Nuryanti, S., Matsjeh, S., Anwar, C. \& Raharjo,
T. J. (2010). Indikator titrasi asam-basa dari ekstrak bunga sepatu (hibiscus rosa sinensis 1). AGRITECH, 30(3), 178-183.

Pursitasari, I. D. (2014). Kimia analitik dasar. Bandung: Alfabeta.

Rahmawati. (2015). Ekstrak bunga dadap merah (erythrina crista-galli l) sebagai indikator asam-basa. Skripsi sarjana pada program studi Pendidikan Kimia Universitas Tadulako Palu., Tidak diterbitkan.

Rein, M. (2005). Copigmentation reactions and color stability of berry anthocyanins. Doctoral dissertation University of Helsinki, Helsinki.

Rukmana, R. (1997). Ubi jalar budidaya dan pasca panen. Yogyakarta: Kanisius.

Siregar, Y. D. I. (2009). Pembuatan kertas indikator asam basa dari bunga kembang sepatu (hibiscus rosa-sinensis 1.). Jurnal Valensi, 1(5), 246-251.

Siregar, Y. D. I. \& Nurlela. (2011). Ekstraksi dan uji stabilitas zat warna alami dari bunga kembang sepatu (hibiscus rosa sinensis l) dan bunga rosela (hibiscus sabdariffa 1). Jurnal Valensi, 2(3), 459-467.

Suda, I., Oki, T., Masuda, M., Kobayaki, M., Nishiba, Y. \& Furata, S. (2003). Review: physiological functionality of purple-flashed sweet potatoes containing anthocyanins and their utilization in foods. Japan Agricultural Research Quarterly, 37(3), 167-173. 